\title{
Posttraumatic Intramuscular Nodular Fasciitis in a 7-Year-Old Boy: Case Report and Review of the Literature
}

\author{
Markus Denzinger $^{I^{*}}$ Sandra Steininger ${ }^{2}$, Niels Zorger $^{2}$, Patricia Reis Wolfertstetter ${ }^{1}$ and Christian Knorr ${ }^{1}$ \\ ${ }^{I}$ Department of Pediatric Surgery, Klinik St. Hedwig, Steinmetzstraße, Regensburg, Germany \\ ${ }^{2}$ Department of Radiology, Krankenhaus Barmherzige Brüder Regensburg, Prüfeninger Straße, Regensburg, Germany
}

\begin{tabular}{l} 
A R T I C L E I N F O \\
\hline Article history: \\
Received: 20 May, 2021 \\
Accepted: 3 June, 2021 \\
Published: 18 June, 2021 \\
\hline Keywords: \\
Nodular fasciitis \\
nodular pseudosarcomatous fasciitis \\
pseudosarcomatous fasciitis \\
subcutaneous pseudosarcomatous \\
fibromatosis
\end{tabular}

\begin{abstract}
A B S T R A C T
Nodular fasciitis is a rare disease, and its diagnosis is difficult. We present a case report of a seven-year-old child with progredient swelling of the left pectoralis muscle three weeks after trauma. After histopathological diagnosis, we performed complete resection. Normally, a conservative approach with regular follow-up is regarded as appropriate since nodular fasciitis does have the capability to regress spontaneously. Since recent publications indicate the possibility of malignant transformation, the complete primary resection also has to be discussed as therapy of choice.
\end{abstract}

\section{Case Report}

A seven-year-old boy was presented to us by his parents in our emergency department. The parents reported swelling of the young boy's left shoulder/pectoralis muscle, which he had noticed after having fallen on it three weeks earlier but which he had not mentioned to them. Since the lump was becoming increasingly painful and the range of motion had reduced due to the pain, he told his parents about it after all and they then presented for consultation. Physical examination revealed a marked and pain-related reduction in range of motion of the left shoulder and arm, especially during abduction and elevation, as well as an obvious lump in the left pectoral area covered by stretched skin. Sonography was performed that showed a lesion of at least, $2.6 \mathrm{~cm}$ suggesting an organized haematoma. However, due to the size of the surrounding reactions, it was not entirely visible in sonography (Figure $1)$.
The parents were told to wait and see how the lesion develops and return for further consultation in case of persistence or progression of either the swelling or the symptoms. Physical examination two weeks later showed a progression in size leading to MR imaging of the boy's thorax. MRI revealed a round, intrapectoral mass of about $2.6 \mathrm{~cm}$ in size with marked perifocal edema and inhomogeneous enhancement of contrast media (Figures $2 \& 3$ ). Since this morphologic description rather matched a tumorous mass than either an inflammatory lesion or haematoma, incisional biopsy was recommended. The patient undergone this procedure two days later. The histological work-up presented the diagnosis of nodular fasciitis of the major pectoralis muscle. The complete resection with preservation of the muscle was performed one week later. The young patient presented to clinical and sonographic follow-up two months after the operation without symptoms or recurrent disease.

${ }^{*}$ Correspondence to: Dr. med. Markus Denzinger, Department of Pediatric Surgery, Klinik St. Hedwig, Steinmetzstraße 1-3, 93049 Regensburg, Germany; Tel: +4909413695301; Fax+4909413695305; E-mail: markus.denzinger@barmherzige-regensburg.de 


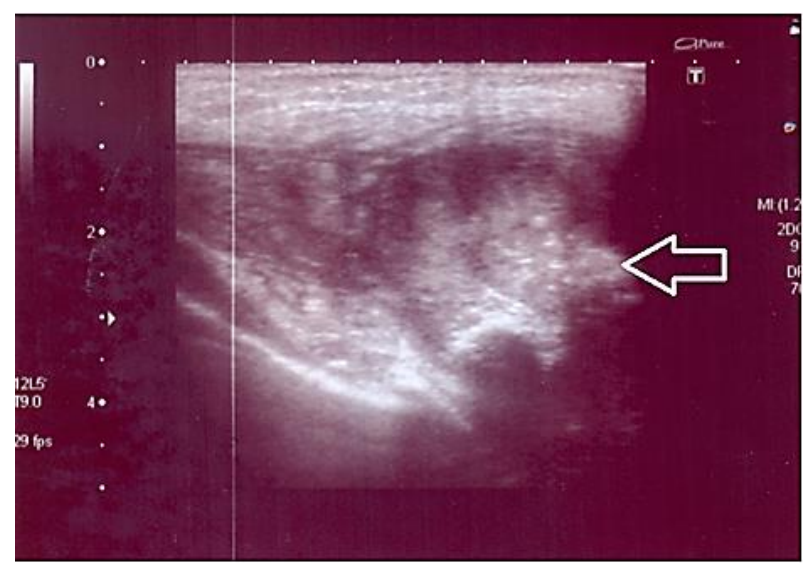

Figure 1: Soft tissue sonography of the left major pectoralis muscle: The linear probe cannot completely depict the extent of the lesion due to its size, making it necessary to use the curved probe with an imaging depth of $9 \mathrm{~cm}$. An intramuscular lesion with a diameter of $2.6 \mathrm{~cm}$, adjacent to the fascia and well distinguishable from other tissues, can be seen. It appears partly hyperechoic and partly hypoechoic compared to the surrounding muscle. The perfusion within the lesion is slightly increased.

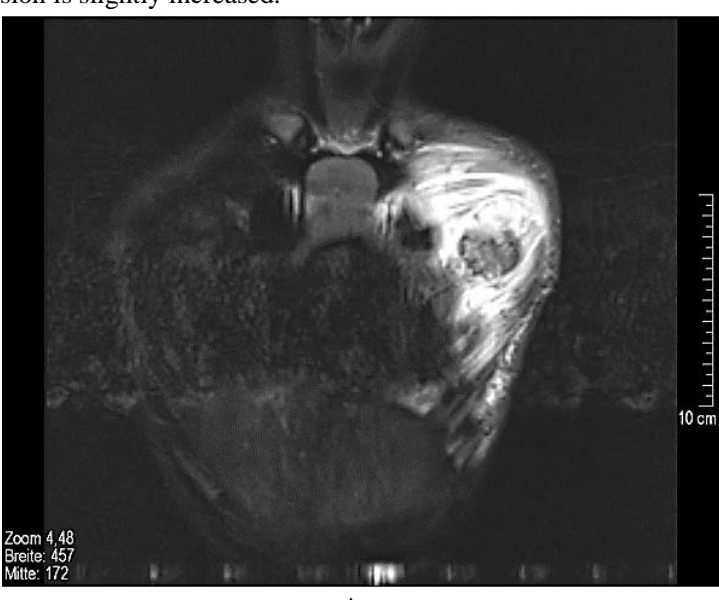

A

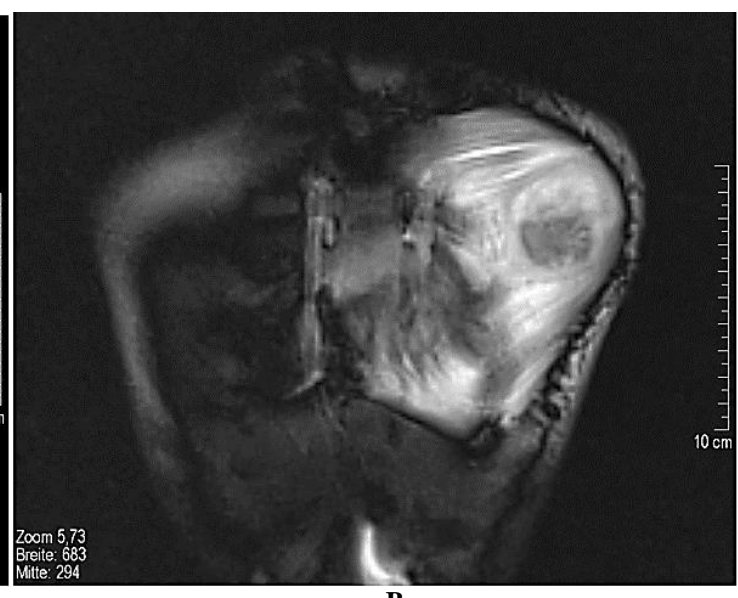

B

Figure 2: Magnetic resonance tomography of the thorax, without contrast media. A) Coronal STIR, B) coronal True-FISP-Sequence: marked edema of the left major pectoralis muscle. Intramuscular mass, approx. $2.6 \mathrm{~cm}$ diameter, which is partly isointense and partly hyperintense compared to the surrounding muscles.

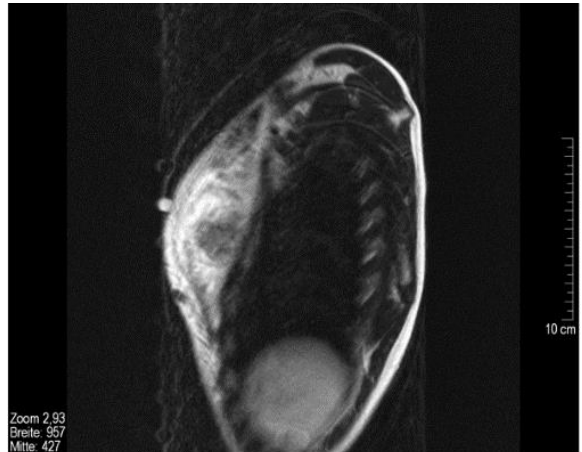

A

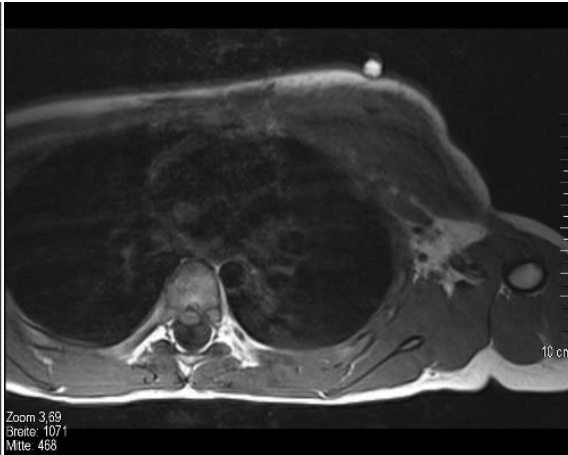

B

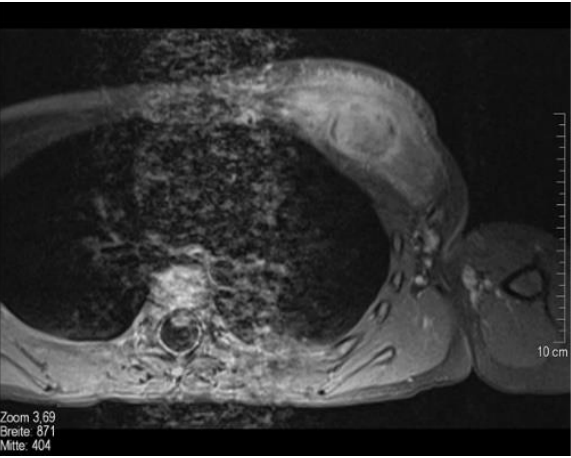

C

Figure 3: Magnetic resonance tomography of the thorax. A) Sagittal T1 SE (with marking), B) transversal T1 TSE, C) transversal T1 fs after administration of contrast media. Extensive, space-occupying edema of the left major pectoralis muscle. Intramuscular mass, approx. $2.6 \mathrm{~cm}$ diameter, which appears partly isointense and partly hyperintense compared to the surrounding muscles in the STIR sequences and isointense in the T1w sequences. Inhomogeneous enhancement of the mass and reactive absorption of contrast media by the edema is seen after administration of contrast media.

\section{Discussion}

Nodular fasciitis (synonyms: nodular pseudosarcomatous fasciitis, pseudosarcomatous fasciitis or subcutaneous pseudosarcomatous fibromatosis) is a pseudotumorous, benign neoplasm of fibrous tissue, which is mainly found subcutaneously but can also be found in intramuscular or fascial positions of extremities or the trunk [1]. The morphologic spectrum is broad, including the classic pattern of delicate fibroblasts suspended in a myxoid matrix, granulation tissue-like areas, solid and whorled myofibroblastic proliferations with multinucleated 
cells, mucoid cysts, and so-called "ancient" forms with dense, refractile strands of keloid-like collagen [2]. Most cases of nodular fasciitis occur in young adults aged 20 to 40 . There is evidence that in general, both sexes are equally affected, while this question is not clearly answered for a pediatric subpopulation probably due to only very small case numbers: some authors state that more girls are affected while others found more boys to be affected [3-5]. According to Wu et al., the upper extremity is the most common localization, while in a pediatric population - which is about $10 \%$ of all cases -it seems to occur predominantly on the trunk or head and neck [4, 6-8]. A variety of locations such as head, neck, parapharyngeal space, cheek, jaw, nose, eye/orbital region, tongue, parotid region, ear, knee, hand, chest, abdominal wall has been described in literature for a pediatric population [9-38].

There is only a little literature on intramuscular nodular fasciitis, such as in our case. The few existing reports state that this variant accounts for up to $10 \%$ of all findings in nodular fasciitis [1]. Not much is known on the pathogenesis of the disease. Assumptions have been made that there is an association to trauma (as in our case) [39]. The lesions can be detected easily in imaging. With ultrasound, they appear as well as distinguishable, mixed hyperechoic and hypoechoic lumps or masses (Figure 1) with slightly increased perfusion of the deep subcutaneous tissue adjacent to the fascia [39]. MRI cannot distinguish the various subtypes of nodular fasciitis such as myxoid, cellular or fibrous. Unfortunately, the morphology is very heterogenic and can mislead to the diagnosis of soft tissue sarcoma [40, 41]. When viewed in T1w sequences, lesions which are rich in cells are nearly isointense compared to musculature and hyperintense compared to fatty tissue in $\mathrm{T} 2 \mathrm{w}$ sequences. Fibrous lesions however are hypointense in all sequences. Usually, the enhancement of contrast media is diffuse but can sometimes be located only peripherally (Figures $2 \& 3$ ) [42]. Biopsy is needed to confirm diagnosis in nearly every case. Genomic rearrangements of the USP6 locus are found in 92\% (44 of 48) of nodular fasciitis [43]. Tomassen et al. recommended molecular analysis of untypical cases to avoid overtreatment due to misdiagnosis, which was previously described [3, 37].

In the past, nodular fasciitis was regarded as benign neoplasia and a conservative approach with follow ups and a surgical excision only in case of a progression are discussed as there are cases with a spontaneous regression and also involution after injection of steroids [44]. Newer publications indicate the possibility of a malignant transformation in isolated cases, so the primary complete surgical excision has to be discussed as therapy of choice [45, 46]. Recurrent disease is rare [8]. The differential diagnosis should include the following (depending on the lesion's localization): M. Dupuytren, desmoid tumors, neurofibromas, fibrous histiocytomas, soft tissue sarcomas and, in cases of intramuscular findings, early-stage myositis ossificans.

\section{REFERENCES}

1. Hansen T, Katenkamp K, Katenkamp D (2006) Intramuscular nodular fasciitis--a clinicopathological study with emphasis on myogenic giant cell. Pathologe 27: 198-203. [Crossref]

2. Montgomery EA, Meis JM (1991) Nodular fasciitis. Its morphologic spectrum and immunohistochemical profile. Am J Surg Pathol 15: 942948. [Crossref]
3. Bernstein KE, Lattes R (1982) Nodular (pseudosarcomatous) fasciitis, a nonrecurrent lesion: clinicopathologic study of 134 cases. Cancer 49 : 1668-1678. [Crossref]

4. Dauendorffer JN, Ortonne N, Bodemer C, Brousse N, Fraitag S et al. (2008) Nodular fasciitis of childhood: a clinicopathological analysis of 10 cases. Ann Dermatol Venereol 135: 553-558. [Crossref]

5. Pandian TK, Zeidan MM, Ibrahim KA, Moir CR, Ishitani MB et al. (2013) Nodular fasciitis in the pediatric population: a single center experience. J Pediatr Surg 48: 1486-1489. [Crossref]

6. Wu SY, Zhao J, Chen HY, Hu MM, Zheng YY et al. (2020) MR imaging features and a redefinition of the classification system for nodular fasciitis. Medicine (Baltimore) 99: e22906. [Crossref]

7. Allen PW (1972) Nodular fasciitis. Pathology 4: 9-26. [Crossref]

8. Bemrich Stolz CJ, Kelly DR, Muensterer OJ, Pressey JG (2010) Single institution series of nodular fasciitis in children. J Pediatr Hematol Oncol 32: 354-357. [Crossref]

9. DiNardo LJ, Wetmore RF, Potsic W (1991) Nodular fasciitis of the head and neck in children. A deceptive lesion. Arch Otolaryngol Head Neck Surg 117: 1001-1002. [Crossref]

10. Handa Y, Asai T, Tomita Y (2003) Nodular fasciitis of the forehead in a pediatric patient. Dermatol Surg 29: 867-868. [Crossref]

11. Hseu A, Watters K, Perez Atayde A, Silvera VM, Rahbar R (2015) Pediatric nodular fasciitis in the head and neck: evaluation and management. JAMA Otolaryngol Head Neck Surg 141: 54-59. [Crossref]

12. Hussein MR (2008) Cranial fasciitis of childhood: a case report and review of literature. J Cutan Pathol 35: 212-214. [Crossref]

13. Qiu Y, Peng R, Chen H, Zhuang H, He X et al. (2020) Atypical nodular fasciitis with a novel PAFAH1B1-USP6 fusion in a 22-month-old boy. Virchows Arch. [Crossref]

14. Patel D, Samson TD, Cochran EL, Zaenglein AL (2021) Nodular fasciitis on the cheek of a child. Pediatr Dermatol 38: 508-509. [Crossref]

15. Antunes SM, Vieira H, Brito A, Oliveira MH (2013) Cervical nodular fasciitis in a 17-month-old child. BMJ Case Rep 2013. [Crossref]

16. Xie S, Liu W, Xiang Y, Dai Y, Ren J (2014) A huge nodular fasciitis in parapharygneal space in a 7-year-old girl: a case report and review of literature. Int J Clin Exp Pathol 7: 9023-9027. [Crossref]

17. Lenyoun EH, Wu JK, Ebert B, Lieberman B (2008) Rapidly growing nodular fasciitis in the cheek of an infant: case report of a rare presentation. Eplasty 8: e30. [Crossref]

18. Yamane H, Tanaka $\mathrm{Y}$, Shimono M, Yamamura T, Takano $\mathrm{N}$ et al. (1986) Nodular fascitis of the mandible in a child. Int J Oral Maxillofac Surg 15: 499-502. [Crossref]

19. Muska EA, Bartal N, Laster Z, Nagler RM et al. (2008) Nodular fasciitis of the maxillofacial region in a pediatric patient. J Otolaryngol Head Neck Surg 37: E188-E190. [Crossref]

20. Cotter CJ, S Finn, P Ryan, D Sleeman (2000) Nodular fascitis of the maxilla in a child. J Oral Maxillofac Surg 58: 1447-1449. [Crossref]

21. Harrison HC, Motbey J, Kan AE, de Silva M (1995) Nodular fasciitis of the nose in a child. Int J Pediatr Otorhinolaryngol 33: 257-264. [Crossref]

22. Chen $Y, L v W, Z h u Z$ (2020) A rapidly progressing mass of nasal cavity in a child: Nodular fasciitis. Ear Nose Throat J. [Crossref]

23. Mukherjee B, Mittal S (2012) Peri-orbital nodular fasciitis in a child. Orbit 31: 124-125. [Crossref] 
24. Holds JB, Mamalis N, Anderson RL (1990) Nodular fasciitis presenting as a rapidly enlarging episcleral mass in a 3-year-old. $J$ Pediatr Ophthalmol Strabismus 27: 157-160. [Crossref]

25. Ruoppi P, Vornanen M, Nuutinen J (2004) A rapidly progressing periorbital mass in an infant: fasciitis nodularis. Acta Otolaryngol 124: 324-327. [Crossref]

26. Recchia FM, Buckley EG, Townshend LM, Klintworth GK (1997) Nodular fasciitis of the orbital rim in a pediatric patient. $J$ Pediatr Ophthalmol Strabismus 34: 316-318. [Crossref]

27. Shupak RP, Horswell BB, Shaffer MD, Plata MJ et al. (2018) Nodular fasciitis of the tongue: A case report in an infant. Int J Pediatr Otorhinolaryngol 113: 99-101. [Crossref]

28. Carr MM, Fraser RB, Clarke KD (1998) Nodular fasciitis in the parotid region of a child. Head Neck 20: 645-648. [Crossref]

29. D'Antonio A, Paolella G, Zeppa P (2012) Rapidly growing intraparotid mass in a young child. J Craniofac Surg 23: e305-e306. [Crossref]

30. Halsey JN, Hohenleitner J, Ciminello FS (2020) Nodular Fasciitis-A Rare Cause of a Rapidly Growing Ear Lesion in a 19-Month-Old Child. Eplasty 20: ic13. [Crossref]

31. Ko PY, Huang MT, Song HL, Lin MCJ (2013) Intra-articular nodular fasciitis of the knee in a 4-year-old girl: a case report and review of the literature. J Pediatr Orthop B 22: 350-352. [Crossref]

32. Gans I, Morrison MJ, Chikwava KR, Wells L (2014) Intra-articular nodular fasciitis of the knee in a pediatric patient. Orthopedics 37: e313-e316. [Crossref]

33. Hara H, Fujita I, Fujimoto T, Hanioka K, Akisue T et al. (2010) Nodular fasciitis of the hand in a young athlete. A case report. Ups J Med Sci 115: 291-296. [Crossref]

34. Kanaya K, Iba K, Yamashita T, Wada T, Hasegawa T (2016) Intraneural Nodular Fasciitis in a Child: A Case Report and Review of the Literature. J Hand Surg Am 41: e299-e302. [Crossref]

35. Brimhall CL, Segura AD, McTigue MK, Esterly NB (1989) Nodular fasciitis on the palm of a child. Arch Dermatol 125: 1441-1442. [Crossref]

36. Suh JH, Yoon JS, Park CB (2014) Nodular fasciitis on chest wall in a teenager: a case report and review of the literature. J Thorac Dis 6 : E108-E110. [Crossref]
37. Tomassen T, van de Ven C, Anninga J, Koelsche C, Hiemcke Jiwa LS et al. (2021) Nodular Fasciitis With Malignant Morphology and a COL6A2-USP6 Fusion: A Case Report (of a 10-Year-old Boy). Int J Surg Pathol. [Crossref]

38. Mazura JC, Matrai C, Spigland N, Brill PW, Kovanlikaya A (2013) Intramuscular nodular fasciitis of the rectus abdominis muscle in an 11year-old girl. Skeletal Radiol 42: 147-150. [Crossref]

39. Jin W, Kim GY, Park SY, Chun YS, Rhyu KH et al. (2010) The spectrum of vascularized superficial soft-tissue tumors on sonography with a histopathologic correlation: Part 2, malignant tumors and their look-alikes. AJR Am J Roentgenol 195: 446-453. [Crossref]

40. Wang XL, De Schepper AMA, Vanhoenacker F, De Raeve H, Gielen J et al. (2002) Nodular fasciitis: correlation of MRI findings and histopathology. Skeletal Radiol 31: 155-161. [Crossref]

41. Coyle J, White LM, Dickson B, Ferguson P, Wunder J et al. (2013) MRI characteristics of nodular fasciitis of the musculoskeletal system. Skeletal Radiol 42: 975-982. [Crossref]

42. Dinauer PA, Brixey CJ, Moncur JT, Fanburg Smith JC, Murphey MD (2007) Pathologic and MR imaging features of benign fibrous softtissue tumors in adults. Radiographics 27: 173-187. [Crossref]

43. Erickson Johnson MR, Chou MM, Evers BR, Roth CW, Seys AR et al. (2011) Nodular fasciitis: a novel model of transient neoplasia induced by MYH9-USP6 gene fusion. Lab Invest 91: 1427-1433. [Crossref]

44. Graham BS, Barrett TL, Goltz RW (1999) Nodular fasciitis: response to intralesional corticosteroids. J Am Acad Dermatol 40: 490-492. [Crossref]

45. Teramura Y, Yamazaki Y, Tanaka M, Sugiura Y, Takazawa Y et al. (2019) Case of mesenchymal tumor with the PPP6R3-USP6 fusion, possible nodular fasciitis with malignant transformation. Pathol Int 69: 706-709. [Crossref]

46. Guo R, Wang X, Chou MM, Asmann Y, Wenger DE et al. (2016) PPP6R3-USP6 amplification: Novel oncogenic mechanism in malignant nodular fasciitis. Genes Chromosomes Cancer 55: 640-649. [Crossref] 